DOI: https://doi.org/10.34069/AI/2021.48.12.21

How to Cite:

Leshchyna, I.V., Asieieva, Yu.O., Vasylieva, O.V., Strelnikova, I.M., \& Kovalska N.A. (2021). Adjustment disorders in international students studying in English during a pandemic. Amazonia Investiga, 10(48), 200-208. https://doi.org/10.34069/AI/2021.48.12.21

\title{
Adjustment disorders in international students studying in English during a pandemic
}

\section{Розлади адаптації як у іноземних студентів, що навчаються англійською мовою в період пандемії}

Received: October 30, 2021

Accepted: December 19, 2021
Written by:

Leshchyna I.V. ${ }^{84}$

https://orcid.org/0000-0002-8053-5288

Asieieva Yu.0. ${ }^{85}$

https://orcid.org/0000-0003-3086-3993

Vasylieva O.V. . $^{6}$

https://orcid.org/0000-0003-0285-8820

Strelnikova I.M. ${ }^{87}$

https://orcid.org/0000-0002-3915-0423

Kovalska N.A. ${ }^{88}$

https://orcid.org/0000-0003-1837-4708

\begin{abstract}
The article presents a detailed study of clinical manifestations of adjustment disorders. The aim of our research to study the peculiarities of adjustment disorders of English speaking international students and to develop a system of its psychotherapeutic correction in a medical institution of higher education.

The research methods: theoretical analysis and generalization of literature on the research topic, psychodiagnostic and mathematical-statistical methods.

The study was conducted in the context in English speaking foreign students of reforming educational services in Ukrainian higher education institutions against the background of the COVID-19 pandemic and distance learning. The study based on 103 English speaking foreign students of III-Vth years of education in Kharkiv National Medical University, both sex (52 male
\end{abstract}

\section{Анотація}

В статті представлено детальне дослідження клінічних проявів розладів адаптації. Мета дослідження: вивчення особливостей розладів адаптації іноземних студентів англомовної форми навчання та розробка системи їх психотерапевтичної корекції в умовах медичного закладу вищої освіти.

Методи дослідження: теоретичний аналіз та узагальнення літератури 3 теми дослідження, психодіагностичні та математикостатистичні методи. Дослідження проводилось в контексті англомовних іноземних студентів щодо реформування освітніх послуг у вищих навчальних закладах України на тлі пандемії COVID-19 та дистанційного навчання. Дослідження проведене на 103 англомовних іноземних студентах III-V курсів Харківського національного медичного університету, обох

\footnotetext{
The article was made as a part of research work of the Department of Psychiatry, Narcology, Medical Psychology and Social Work of Kharkiv National Medical University on the topic: To investigate the mental health of people who have relapsed COVID - 19 (phenomenology of mental disorders, therapy, rehabilitation)

${ }^{84}$ Associate Professor, PhD, MSc, MD Vice-Rector for Research and Education of Kharkiv National Medical University Ukraine, Ukraine.

${ }^{85}$ Doctor of Psychological Sciences, senior lecturer at the Department of Psychiatry, Medical and Special Psychology of the State institution «South Ukrainian National Pedagogical University named after K.D. Ushynsky», Odessa, Ukraine.

${ }^{86}$ Associate Professor, PhD, MD Dean of VII Faculty for International Students of Kharkiv National Medical University Ukraine, Ukraine.

${ }^{87}$ Associate Professor, PhD, MD Associate Professor of the Department of Psychiatry, Narcology, Medical Psychology and Social Work of Kharkiv National Medical University Ukraine, Ukraine.

${ }^{88} \mathrm{PhD}$, Senior Lecturer of the Department of Language and Psychological and Pedagogical Training of the Odesa National Economic University, Odesa, Ukraine.
} 


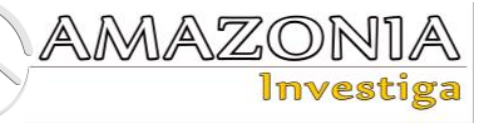

and 51 female). The average age of the surveyed foreign students was $22.0 \pm 1.8$ years. Foreign students were divided into three groups. The first group included 40 fourth-year students, the second group 40 third-year students, the third group consisted of 23 fifth-year students. The survey consisted of several stages and was conducted on-line. The first stage was carried out at the beginning of the quarantine, the second after 3 months. Psycho-corrective measures had a positive effect on the dynamics of mental state in $82.5 \%$ of international students. In $68.7 \%$ there was a reduction in maladaptation.

Keywords: adjustment disorders, online learning, COVID-19 pandemic, anxiety, depression, psychosomatic disorders, foreign students.

\section{Introduction}

The internalization of higher education is conditioned by globalization of the modern world. High-quality training of specialists and accessibility of higher education encourages foreign citizens to study in higher education institutions of Ukraine.

Today in Ukrainian higher education institutions the process of transformation of educational services continues, the need for comprehensive reform of the education system in general, and in particular, the field of training of foreign medical students. Significantly changed the regime and increased the intensity of the educational process, as well as increased the educational workload. Studying in institution of a higher education is characterized by a variety of overloads and requirements for the individual, educational activities can be a source of difficult situations that make high demands on young people. Adjustment disorders prevent the manifestation of important personality traits that are formed through education (Nahas, Elkalmi, Al-Shami, \& Elsayed, 2019; Bruffaerts, Mortier, Kiekens, Auerbach, Cuijpers, Demyttenaere et al., 2018; Jacobson, Lekkas, Price, Heinz, Song, O'Malley et al., 2020)

The fundamentality of Ukrainian medical education makes Ukraine attractive to foreigners from all over the world. In this regard, it becomes important to study the problems of adaptation of international students to the educational process in the Ukrainian institution of higher education. (Kozhyna, Marakushyn, Zelenska, Khaustov, Mykhaylov, \& Zelenska, 2018; Malakhov, Asieieva, Volinko, \& Kharitonova, 2016). статей (52 чоловіки та 51 жінка). Середній вік опитаних іноземних студентів становив $22,0 \pm 1,8$ року. Іноземних студентів розділили на три групи. Перша група включала 40 студентів четвертого курсу, друга група - 40 студентів третього курсу, третя група складалася 323 студентів п'ятого курсу. Опитування складалося 3 декількох етапів і проводилося в режимі он-лайн. Перший етап проводився на початку карантину, другий через 3 місяці. Психокорекційні заходи позитивно вплинули на динаміку психічного стану у $82,5 \%$ іноземних студентів. У $68,7 \%$ відмічено редукцію дезадаптиіних станів.

Ключові слова: розлади адаптації, онлайннавчання, пандемія COVID-19, тривога, депресія, психосоматичні розлади, іноземні студенти.

Studying in a higher education institution is characterized by a variety of overloads and requirements for the individual, educational activities can be a source of complex situations that make high demands on students. Adjustment disorders prevent the manifestation of important personality traits that are formed through education. One of the most important pedagogical tasks of any higher education institution is to work with students, aimed at their faster and more successful adaptation to the education system, to the new system of social relations, to their development of a new students role. (Kozhyna, Mykhaylov, \& Viyun, 2017).

Foreign students are special social group, which is united by age, specific working and living conditions. After enrollment in a higher education institution, a foreign student finds himself in new social and psychophysiological conditions (other language, culture, religion, climate, etc.), in addition, this is the period of completion of the formation of the student's personality. The physiological process of adaptation should start in this period, it's successfully happens to most foreign students (Fitzpatrick, Biesma, Conroy, \& McGarvey, 2019; Huckins, daSilva, Wang, Hedlund, Rogers, Nepal et al., 2020).

An additional burden on all categories of the student community and on foreign students in particular is the involvement in the changed role of online learning, which is accompanied by additional tension and stress. Some international students have made significant progress in online learning, but living alone in the quarantine 
conditions of the COVID-19 pandemic and the realities of distance learning have a negative impact on students' physical and mental health (Torous, Jän Myrick, Rauseo-Ricupero, \& Firth, 2020; De Oliveira Araújo, de Lima, Cidade, Nobre, \& Neto, 2020).

Today, the reference indicators of students' adaptability to educational activities are the absence or low level of anxiety and high level of self-esteem, sufficient level of communication, satisfactory well-being, emotional comfort and balance (Zhai, \& Du, 2020; Wang, \& Zhao, 2020).

\section{Theoretical Framework or Literature Review}

The intensive process of studying at a medical university places increased demands on the mechanisms of mental adaptation, especially if there is a situation of uncertainty and changes in forms of learning (quarantine, forced long-term isolation, transfer to distance learning, uncertainty and delay in compiling KROK) (Kozhyna, Marakushyn, Zelenska, Khaustov, \& Zelenska, 2017; Vashkite, \& Khaustov, 2019).

Influence of long-term stress and the situation of uncertainty induce morphological, physiological, neurochemical changes in the brain, which are the foundation of the development of psychosomatic disorders. The combination of morphological and functional components, their expressiveness, ratio and regional specificity determine the predisposition to a disease and its clinical features (Kwaah, \& Essilfie, 2017; Locke, 2019; Baghurst, \& Kelley, 2014; Brooks, Webster, Smith, Woodland, Wessely, Greenberg et al., 2020).

The development of students maladaptation during professional training is a major psychological, medical and socio-economic problem, which adversely affects the effectiveness of future professional activities of medical students. The prevalence of adjustment disorders in the student population, according to the literature ranges from $5.8 \%$ to $61.35 \%$. They cause a decrease in efficiency, deterioration of educational adaptation and academic performance, as well as the quality of students life.

Forced lifestyle changes in the situations of the COVID-19 pandemic and online learning increase anxiety, feelings of loneliness, lead to exhaustion and even the development of signs of anxiety and depression among international students. The development of maladaptation of foreign students in modern Ukrainian realities is a priority psychological, medical and socioeconomic problem, it can negatively affect the effectiveness of professional activities of foreign students and lead to the development of psychosomatic disorders and diseases in future (Nelson, Pettitt, Flannery, \& Allen, 2020; Cao, Fang, Hou, Han, Xu, Dong et al., 2020).

The above indicates the need for in-depth study of socio-psychological, clinicalpsychopathological and pathopsychological features of the formation of psychological adjustment disorders in international students, which will create a basis for developing a system of psychotherapeutic correction and psychoprophylactic support for students in medical institution of higher education.

The aim of ourresearch to study the peculiarities of adjustment disorders of Englishspeaking international students and to develop a system of its psychotherapeutic correction in a medical institution of higher education.

The research methods: theoretical analysis and generalization of literature on the topic of research, psychodiagnostics, and mathematical and statistical methods.

The theoretical method includes theoretical and methodological analysis, generalization of social, medical and psychological achievements on the topic of research, which was study the peculiarities of adjustment disorders of English speaking international students.

In compliance with the principles of bioethics and medical deontology, a comprehensive survey of 103 foreign students of III-Vth years of education in Kharkiv National Medical University, both sexes (52 men and 51 women) studying in English were conducted. The mean age of the subjects was $22.0 \pm 1.8$ years. Students were divided into three groups. The first group included 40 fourth-year students, the second group 40 third-year students, the third group consisted of 23 fifth-year students. The survey was conducted on-line in several stages: the first stage was conducted at the beginning of the quarantine, the second after 3 months.

The psychodiagnostic complex was aimed at studying the characteristics of the psychoemotional state for the study of which a screening test was used of screening test PHQ-9 (Kroenke, Spitzer, \& Williams, 2001), scale of nervous and mental tension according to T.A. Nemchin (Nemchin, 1983), clinical scales - The Hamilton 


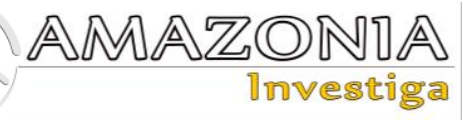

Anxiety Rating Scales (Hamilton, 1959); clinical scales - The Hamilton Depression Rating Scales (Hamilton, 1960).

Mathematical and statistical processing of the study results was performed using specialized software packages (Statistica 6.0, MS Excel) using the Student's t-test methodology.

The work was performed in accordance with the research plan of the Department of Psychiatry, Narcology, Medical Psychology and Social Work of Kharkiv National Medical University of the Ministry of Health of Ukraine on the topic "To develop a prevention system of nonpsychotic mental disorders and rehabilitation of hostilities victims", state registration No 0119 U002902.

\section{Results and Discussion}

At the first stage of the study, levels of adaptation were screened and foreign students with adjustment disorders were identified. At the intermediate stage, a comprehensive analysis of clinical manifestations and mechanisms of formation of maladaptation in international students was done. The second stage was a screening for psychosomatic disorders. The final phase of the research was the development of approaches to psychocorrection and psychoprophylaxis of adjustment disorders in international students.

According to the results of the study, international students of groups I and II have a fairly high level of maladaptation in comparison with students of group III. This indicator was found in $10.67 \%$ of students of group I, $6.4 \%$ of students of group II and $0.9 \%$ of students of group III, which in turn in the conduct of active psychological interventions with prescribing medicines. The presence of a high level of maladaptation required the provision of mandatory psychological assistance and a readaptation program. These measures were necessary for foreign students of I $(9.8 \%)$ and II (12\%) groups. International students of the $1 \mathrm{st}$ (30.2\%), 2nd (26.7\%) and $20.8 \%$ of the 3rd groups had a moderate level of maladaptation and needed professional advice.
During the work, a certain pattern was revealed: international students with a higher level of maladaptation did not consider it necessary to receive psychological or medical care and could even neglect it.

The screening revealed such risk factors for the development of maladaptation of foreign students as increased workload (43.1\% of students of group I, $29.6 \%$ of students of group II, $28.6 \%$ of students of group III), lack of time for rest (in $31.1 \%$ of students of group I, $23.1 \%$ of students of group II, $24.2 \%$ of students of group III), previous trauma ( $17.9 \%$ of students of group I, $16.6 \%$ of students of group II, $15.4 \%$ of students III group), insufficient adaptation to distance learning (27.9\% of students of group I, $39.5 \%$ of students of group II, $19.3 \%$ of students of group III), inability to go home $(19.3 \%$ of students of group I, $14.5 \%$ of students of group II, $17.7 \%$ of students of group III), imperfection of mechanisms of psychological protection (26.1 $\%$ of students of group I, $25.3 \%$ of students of group II, $23.7 \%$ of students of group III).

The clinical picture of adjustment disorders of international students was dominated by complaints of attention deficit, memory impairment, obsessions, fears, confusion, anhedonia, hypertension, asthenia, reluctance to communicate, anxiety, sadness and longing, depression, sleep-wake cycle, uncertainty of the future.

It is noteworthy that the excessive anxiety of international students was due to the next postponement of the KROK, the inability to go home, increased workload and insufficient adaptation to distance learning. Asthenic manifestations were characteristic of most international students and manifested themselves in sleepiness, decreased ability to learn, difficulty concentrating, difficulty switching from one activity to another, rapid fatigue.

The study showed that the general characteristics of the clinical manifestations of adjustment disorders in foreign students were mostly premorbid and are presented in table 1 . 
Table 1.

General characteristics of clinical manifestations for adjustment disorders in international students.

\begin{tabular}{lll}
\hline \multirow{2}{*}{$\begin{array}{l}\text { General characteristics } \\
\text { clinical manifestations }\end{array}$} & \multicolumn{2}{l}{$\begin{array}{l}\text { Number of international students } \\
(\mathrm{n}=103)\end{array}$} \\
\cline { 2 - 3 } $\begin{array}{l}\text { Disturbance of night sleep } \\
\text { Redused capacity for work }\end{array}$ & 32 & $\mathrm{P} \% \pm \mathrm{s} \%$ \\
Autonomic disturbances & 45 & $31.07 \pm 3.54$ \\
emotional tension, exacerbation of personality and typological traits & 30 & $29.1 \pm 3.44$ \\
loss of the ability to adapt to what is happening; loss of "flexibility and & 26 & $25.24 \pm 2.78$ \\
plasticity in communication" & 19 & $18.45 \pm 2.27$ \\
Premorbid violations & 65 & $63.1 \pm 4.08$ \\
The disorders reached the syndrome level & 17 & $16.50 \pm 1.66$ \\
\hline
\end{tabular}

The surveyed foreign students showed such alarming symptoms of manifestations of adjustment disorders as anxiety, nervousness $35.92 \pm 3.86 \%$, irritability $23.30 \pm 2.98 \%$, agitation-restlessness $18.45 \pm 1.96 \%$, impatience

Table 2.

General anxiety symptoms of adjustment disorders in international students.

\begin{tabular}{llc}
\hline & \multicolumn{2}{c}{$\begin{array}{l}\text { Number of foreign students } \\
(\mathrm{n}=103)\end{array}$} \\
\cline { 2 - 3 } Common anxiety symptoms & $\mathrm{abs.}$ & $\mathrm{P} \% \pm \mathrm{s} \%$ \\
Feeling of anxiety, nervousness & 37 & $35.92 \pm 3.86$ \\
Irritation & 24 & $23.30 \pm 2.98$ \\
Excitement-restlessness & 19 & $18.45 \pm 1.96$ \\
Impatience & 22 & $21.36 \pm 2.78$ \\
Decreased concentration of attention, disturbing thoughts & 44 & $42.72 \pm 4.02$ \\
Sleep disturbances, early wake-ups or nightmares & 31 & $30.1 \pm 3.54$ \\
Rapid fatigue & 28 & $27.18 \pm 2.82$ \\
\hline
\end{tabular}

The clinical picture of autonomic, stress-related symptoms of adjustment disorders in international students was dominated by dry mouth $26.21 \pm 2.98 \%$, tachycardia $32.04 \pm 4.01 \%$, a feeling of tightness in the chest $11.65 \pm 1.78 \%$, fever or chills $25.24 \pm 2.73 \%$, abdominal pain, diarrhea $37.86 \pm 4.24 \%$, increased urination

Table 3.

Vegetative, stress-related symptoms of adjustment disorders in international students.

\begin{tabular}{lll}
\hline & \multicolumn{2}{c}{$\begin{array}{l}\text { Number of international students } \\
\text { (n=103) }\end{array}$} \\
\cline { 2 - 3 } Vegetative, stress-related symptoms & 27 & $\mathrm{P} \% \pm \mathrm{s} \%$ \\
dry mouth & 33 & $32.04 \pm 4.01$ \\
Tachycardia & 12 & $11.65 \pm 1.78$ \\
feeling of tightness in the chest & 26 & $25.24 \pm 2.73$ \\
attacks of fever or chills & 39 & $37.86 \pm 4.24$ \\
abdominal pain, diarrhea & 25 & $24.27 \pm 2.06$ \\
increased urination & 28 & $27.18 \pm 1.66$ \\
feeling of lump in the throat, shortness of breath & 44 & $42.72 \pm 4.25$ \\
sweating, cold and wet palms & 13 & $12.62 \pm 0.96$ \\
dizziness & 26 & $25.24 \pm 2.73$ \\
tremor, muscle twitching, flinches, tremors, increased skeletal muscle & 26 \\
tone, myalgia & & 2 \\
\hline
\end{tabular}

$24.27 \pm 2.06 \%$, feeling lump in the throat, shortness of breath $27.18 \pm 1.66 \%$, sweating, cold and wet palms $42.72 \pm 4.25 \%$, dizziness $12.6 \pm 0.96 \%$, tremor, muscle twitching, tremors, tremors increase skeletal muscle tone, myalgia $25.24 \pm 2.73 \%$ (Table 3 ).
$21.36 \pm 2.78 \%$, decreased concentration, anxious thoughts $42.72 \pm 4.02 \%$, sleep disturbances, early orenings or nightmares $30.1 \pm 3.54 \%$, rapid fatigue $27.18 \pm 2.82 \%$ (Table 2 ). 


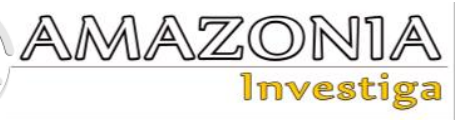

Analysis of clinical manifestations of psychosomatic disorders of various body systems in international students revealed disorders of the gastrointestinal tract (nausea, increased or slowed motility) $20.39 \pm 2.68 \%$, disorders of the cardiovascular system (palpitations, fluctuations) blood pressure,

Table 4.

Clinical manifestations of psychosomatic disorders of various body systems in international students.

\begin{tabular}{|c|c|c|}
\hline \multirow[t]{2}{*}{ General anxiety symptoms } & \multicolumn{2}{|c|}{$\begin{array}{l}\text { Number of international students } \\
(\mathrm{n}=103)\end{array}$} \\
\hline & abs. & $\mathrm{P} \% \pm \mathrm{s} \%$ \\
\hline disorders of the gastrointestinal tract (nausea, increased or slowed motility) & 21 & $20.39 \pm 2.68$ \\
\hline $\begin{array}{l}\text { disorders of the cardiovascular system (palpitations, fluctuations in blood } \\
\text { pressure, narrowing or dilation of blood vessels) }\end{array}$ & 19 & $18.44 \pm 2.78$ \\
\hline from the respiratory system (acceleration or deceleration of respiration) & 17 & $16.50 \pm 1.96$ \\
\hline from the muscular system (excitement, tremor) & 20 & $19.41 \pm 2.78$ \\
\hline alexithymia & 31 & $30.09 \pm 2.66$ \\
\hline premenstrual tension syndrome & 15 & $14.56 \pm 1.02$ \\
\hline erectile dysfunction & 9 & $8.73 \pm 0.54$ \\
\hline
\end{tabular}

The clinical structure of adjustment disorders was represented by depressive $(25.24 \%$ of international students of group I, $22.33 \%$ of group II and $21.36 \%$ of group III), neurasthenic (22.33\% of foreign students of group I, $26.21 \%$ of international students of group II and $27.18 \%$ of foreign students of group III), anxious (28.16 $\%, 25.24 \%$ and $23.30 \%$ of foreign students, respectively) and dissociative (26.21\% of surveyed foreign students of group I, $22.33 \%$ of group II and $24.27 \%$ of group III, respectively) syndrome complexes. The peculiarity of these maladaptive states was associated with massive somatization and was characterized by polymorphic vegetative-visceral disorders, disruption of the sleep-wake cycle.

Depressive disorders in international students were clinically manifested by low mood during the day, sometimes anxiety or indifference to himself, his future, guilt, feelings of hopelessness or probable misfortune, prolonged inaction, which was replaced by restlessness, anxiety, unproductive fussiness, slowing of thoughts, motor retardation; decreased self-esteem and self-confidence, self-blame, lack or decrease in interest in learning, focus on physical health on the PHQ-9 screening scale (severe depression) and the clinical scale of anxiety and depression Hamilton (severe depression and moderate anxiety).

In international students of group II, along with the emotional signs of depressive disorder revealed somatovegetative disorders, clinical signs of asthenic manifestations, unmotivated irritability, turbulence of emotional vasoconstriction or dilation) $18.44 \pm 2.78 \%$, from the respiratory system (acceleration or deceleration of respiration) $16.50 \pm 1.96 \%$, from the muscular system (excitation, tremor) $19.41 \pm 2.78 \%$, alexithymia was detected in $30.09 \pm 2.66 \%$, premenstrual tension syndrome $14.56 \pm 1.02 \%$, erectile dysfunction $8.73 \pm 0.54 \%$. manifestations, which did not correspond in strength to the external stimulus.

Neurasthenic syndrome in international students had the following clinical signs: a constant feeling of fatigue, which was exacerbated by mental or physical exertion, excessive irritability and hypersensitivity in response to the usual intensity of external influences, clinical manifestations of moderate depression on a screening scale PHQ-9 and manifestations of anxiety and severe depression on the clinical scale of anxiety and depression Hamilton. For the second group of international students, along with the above manifestations, were characterized by hypersensitivity, episodic lacrimal reactions and shallow sleep with frequent awakenings.

Manifestations of anxiety syndrome complex were feelings of anxiety, nervousness, irritability and impatience, excitement and restlessness, mild mood swings, difficulty concentrating, fatigue, moderate depression on the PHQ-9 screening scale, moderate manifestations of depression and major depression and anxiety Hamilton. International students of group II had more violent manifestations of autonomic disorders; they were characterized by decreased concentration, constant anxiety, sleep disturbances, early awakenings, frequent nightmares, poor appetite or overeating, restlessness, excitement.

The dissociative syndrome complex in international students was clinically manifested by bright and violent emotional reactions, which 
did not differ in the depth of feelings, unmotivated irritability, resentment, theatrical behavior aimed at the immediate environment, mannerisms, lively facial expressions and mild depression manifestations of depression and anxiety on the scale of anxiety and depression of Hamilton. Psycho-emotional overload or adverse psychogenic factors provoked headaches in international students of the second group, as well as affective reactions of different intensity and duration.

The analysis of the level of nervous and mental stress in the structure of maladaptive states of international students showed the predominance of students of groups I and II (37.2 \% and 37.4 $\%$, respectively) intensive (moderate) and students of group III (38.1 \%) extensive excessive) voltage.

The correlation analysis of the obtained data revealed close relationships between the presence of adjustment disorders of foreign students and increased workload $(\mathrm{r}=0.66)$, lack of time for rest $(\mathrm{r}=0.60)$, previous trauma $(\mathrm{r}=0.57)$, insufficient adaptation to distance learning $(\mathrm{r}=0.61)$ imperfection of psychological protection mechanisms $(\mathrm{r}=0.59)$, inability to go home $(r=0.61)$, the presence of chronic diseases $(r=0.62)$, being in situations of excessive nervous and mental stress $(\mathrm{r}=0.61)$, severity of depression on the PHQ-9 screening, severe anxiety and depression on the Hamilton scale $(r=0.60)$.

The study allowed offering a comprehensive system for the correction of adjustment disorders of international students in the form of psychotherapy, pharmacotherapy and psychoeducation.

Psychotherapy was selected individually for each international student, depending on the identified variant of adjustment disorder. Thus, in the depressive version of the disorder of adaptation, preference was given to cognitive-behavioral psychotherapy according to Beck, art therapy "Picture of yourself" and rational psychotherapy according to P. Dubois. In the neurasthenic variant, personality-oriented therapy was prescribed according to B. Karvasarsky, G. Insurina, V. Tashlykov, psychotonic variant of autogenic training by A. Shogam, K. Mirovsky and cognitive-behavioral therapy according to Beck. If an alarming variant of adjustment disorder was detected, Art Therapy "Star of Senses", personality-oriented therapy according to B. Karvasarsky, G. Insurina, V. Tashlykov and cognitive-behavioral therapy according to Beck were performed. Identification of the dissociative variant of adjustment disorder in a international student made it possible to prescribe autogenic training of M. Lebedynsky T. Bortnyk, short-term psychodynamic psychotherapy according to B. Karvasarsky, cognitive-behavioral therapy of Beck and psychotonic version of autogenic training of A. Shorovsky, K. Shogam, K. Shogam.

To accelerate the response to psychotherapeutic intervention, students were recommended pharmacotherapy, which was aimed at increasing the adaptive-compensatory potential of the body and prevent further progression of the processes of maladaptation of CNS functions under prolonged stress. Students were recommended to take adaptogens, vegetative stabilizers, phytosedatics and multivitamin complexes.

Psycho-educational activities were an integral part of helping international students to restore stress and counteract the development of psychosomatic disorders. Psycho-educational assistance was provided in the form of psychoeducational modules with problem-oriented discussions, information training, training of positive self-perception, training in solving interpersonal problems and communication training. Each module consisted of 8 lessons lasting 1 hour. Psycho-educational classes were held in closed groups with the number of foreign students from 8 to 10 people twice a week. The purpose of psycho-educational interventions was to provide international students with comprehensive and substantiated information on adaptive disorders and risks of psychosomatic diseases, training in coping with stress, coping in situations of uncertainty, recognizing the first signs of maladaptive manifestations and reducing emotional stress.

The complex system of correction of the revealed disorders of adaptation in international students allowed receiving the expressed decrease in levels of anxiety and depression. Positive dynamics in the emotional state of international students can be traced from the second week and reaches maximum results in the sixth, which is confirmed by the scales of anxiety and depression Hamilton on re-examination (reduction of anxiety to 10 and depression to 8 points).

Psycho-corrective interventions also had a positive effect on the state of nervous and mental tension of international students with disorders of adaptation on the scale of T.A. Nemchin. Detective (weak) NMT decreased from $28.6 \%$ to $63.5 \%$, intensive (moderate) NMT decreased 


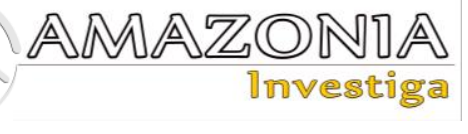

from $34.3 \%$ to $29.5 \%$ and extensive (excessive) NM decreased from $28.7 \%$ to $1.6 \%$.

\section{Conclusions}

1. According to the results of the study, the presence of adjustment disorders in international students in the form of depressive, neurasthenic, anxiety and dissociative syndrome complexes was revealed.

2. The most pronounced violations of adaptation were found in international students of the IV year of study (II group of subjects).

3. The obtained results made it possible to use a comprehensive system of correction of adjustment disorders of international students, which consisted of psychotherapy, pharmacotherapy and psycho-education.

4. Psycho-corrective measures had a positive effect on the dynamics of mental state in $82.5 \%$ of international students. In $68.7 \%$ there was a reduction in maladaptation.

5. Repeated psycho-diagnostic studies confirmed the prevention of psychosomatic disorders in $89.6 \%$ of international students. Increased psychophysical activity, increased self-confidence and capabilities were recorded in $66.5 \%$ of foreign students.

\section{Bibliographic references}

Baghurst, T., \& Kelley, B. C. (2014). An examination of stress in college students over the course of a semester. Health Promot Pract, 15(3), 438-447. https://pubmed.ncbi.nlm.nih.gov/24231633/

Brooks, S. K., Webster, R. K., Smith, L.E., Woodland, L., Wessely, S., Greenberg, N., et al. (2020). The psychological impact of quarantine and how to reduce it: rapid review of the evidence. Lancet, 14, 395(10227), 912-920.

https://www.thelancet.com/journals/lancet/ar ticle/PIIS0140-6736(20)30460-8/fulltext

Bruffaerts, R., Mortier, P., Kiekens, G., Auerbach, R. P., Cuijpers, P., Demyttenaere, K., et al. (2018). Mental health problems in college freshmen: prevalence and academic functioning. $\mathbf{J}$ Affect Disord, 225, 97-103. https://pubmed.ncbi.nlm.nih.gov/28802728/

Cao, W., Fang, Z., Hou, G., Han, M., Xu, X., Dong, J., et al. (2020). The psychological impact of the COVID-19 epidemic on college students in China. Psychiatry Res, 287, 112934.
https://www.ncbi.nlm.nih.gov/pmc/articles/P MC7102633/

De Oliveira Araújo, F. J., de Lima, L. S. A., Cidade, P. I. M., Nobre, C. B., \& Neto, M. L. (2020). Impact of Sars-Cov-2 and its reverberation in global higher education and mental health. Psychiatry Res, 288, 112977. https://pubmed.ncbi.nlm.nih.gov/32302818/

Fitzpatrick, O., Biesma, R., Conroy, R. M., \& McGarvey, A. (2019). Prevalence and relationship between and clinical medical students in Ireland. BMJ Open, 9(4), e023297.

https://pubmed.ncbi.nlm.nih.gov/31048421/

Hamilton, M. (1959). The assessment of anxiety states by rating. Br J Med Psychol, 32, 50-55. https://dcf.psychiatry.ufl.edu/files/2011/05/ HAMILTON-ANXIETY.pdf

Hamilton, M. (1960). A rating scale for depression. J Neurol Neurosurg Psychiatry, 23, 56-62. https://dcf.psychiatry.ufl.edu/files/2011/05/ HAMILTON-DEPRESSION.pdf

Huckins, J. F., daSilva, A. W., Wang, W., Hedlund, E., Rogers, C., Nepal, S. K., et al. (2020). Mental health and behavior of college students during the early phases of the COVID-19 pandemic: longitudinal smartphone and ecological momentary assessment study. J Med Internet Res, 22(6), e20185 https://www.jmir.org/2020/6/e20185/

Jacobson, N. C., Lekkas, D., Price, G., Heinz, M. V., Song, M., O'Malley, A. J., et al. (2020). Flattening the mental health curve: COVID-19 stay-at-home orders are associated with alterations in mental health search behavior in the United States. JMIR Ment Health, 01, 7(6), e19347. https://www.ncbi.nlm.nih.gov/pmc/articles/P MC7265799/

Kozhyna, H., Marakushyn, D., Zelenska, K., Khaustov, M., Mykhaylov, V., \& Zelenska, G. (2018). Psychological manifestations of maladjustment to educational activities. European Psychiatry. 48. 545-546. https://www.cambridge.org/core/journals/eur opean-

psychiatry/issue/4ECFAAF7AB606F9A17D C295BA919D4A7

Kozhyna, H., Mykhaylov, V., Viyun, V. (2017). The phenomenon of psychological adaptation to the professional activities of doctors. European psychiatry, 41, 690. https://www.cambridge.org/core/journals/eur opean-

psychiatry/issue/440EC98317BD222622C74 A0FF1A44E29 
Kozhyna, G. M., Marakushyn, D. I., Zelenska, K. O., Khaustov, M. M., Zelenska, G. M. (2017). Individual-psychological and physiological manifestations of maladjustment to educational activities. Inter collegas, 3(4), 146-149.

https://inter.knmu.edu.ua/article/view/196/1 87

Kroenke, K., Spitzer, R. L., \& Williams, J. B. (2001). The PHQ-9: validity of a brief depression severity measure. J Gen Intern Med., 16(9), 606-13. https://pubmed.ncbi.nlm.nih.gov/11556941/

Kwaah, C. Y., \& Essilfie, G. (2017). Stress and coping strategies among distance education students at the university of Cape Coast, Ghana. Turkish Online Journal of Distance Education - TOJDE, 18, 3 (8), 120-134. https://files.eric.ed.gov/fulltext/EJ1147588.p df

Locke, B. (2019). annual report. Center for Collegiate Mental Health. Park P.A. University: Penn State University. https://ccmh.memberclicks.net/assets/docs/2 019-CCMH-Annual-Report_3.17.20.pdf

Malakhov, P.V., Asieieva, Yu.O. Volinko, V.V. \& Kharitonova, A.S. (2016) Problems of adaptation of medical students. Medical psychology, № 2[42] p. 3-6. http://www.mps.kh.ua/archive/2016/2/1

Nahas, A. R. M. F., Elkalmi, R., Al-Shami, A., \& Elsayed, T. (2019). Prevalence of depression among health sciences students: findings from a public university in Malaysia. J Pharm Bioallied Sci, 11(2), 170-175. https://pubmed.ncbi.nlm.nih.gov/31148894/
Nelson, B., Pettitt, A., Flannery, J., \& Allen, N. (2020). Rapid assessment of psychological and epidemiological correlates of COVID-19 concern, financial strain, and health-related behavior change in a large online sample. Int J Methods in Psychiatr, 21(3), 169-184. https://journals.plos.org/plosone/article?id=1 0.1371/journal.pone.0241990

Nemchin, T.A. (1983). States of nervous and mental stress. Leningrad, Leningrad University, 167. https://www.twirpx.com/file/802484/

Torous, J., Jän Myrick, K., Rauseo-Ricupero, N., \& Firth, J. (2020). Digital mental health and COVID-19: using technology today to accelerate the curve on access and quality tomorrow. JMIR Ment Health, 7(3), e18848. https://mental.jmir.org/2020/3/e18848/

Vashkite, I., \& Khaustov, M. (2019). Features of the clinical picture of depressive disorders of different registers in university students. Inter collegas, $\quad 2(6), \quad 112-119$. https://inter.knmu.edu.ua/article/view/298/2 81

Wang, C., \& Zhao, H. (2020). The impact of COVID-19 on anxiety in Chinese university students. Front Psychol, 11, 1168. https://www.frontiersin.org/articles/10.3389/ fpsyg.2020.01168/full

Zhai, Y., \& Du, X. (2020). Mental health care for international Chinese students affected by the COVID-19 outbreak. Lancet Psychiatry, 7(4), e22. https://pubmed.ncbi.nlm.nih.gov/32199511/ 